近藤祉秋

\title{
（北海道大学アイヌ・先住民研究センター） \\ Contemporary situations of subsistence activities and traditional foods among Alaska Natives through food sovereignty perspective
}

\author{
Shiaki Kondo \\ Center for Ainu and Indigenous Studies, Hokkaido University, \\ Kita 8, Nishi 6, Kita-ku, Sapporo-shi, Hokkaido, 006-0808 \\ 干006-0808 北海道札幌市北区北 8 条西 6 丁目
}

\begin{abstract}
Indigenous communities throughout Interior Alaska have actively engaged in various activities aimed to revitalize their traditional subsistence activities and food cultures. These are sometimes called "culture camp." This paper briefly discusses them through food sovereignty perspective. First, "culture camp" can be seen as an effort by indigenous communities and their non-native collaborators to regain the control over the education of Alaska Native youths in the hands of the community. Second, hunters can apply for exemptions for the out-of-season hunting if the activities are for education purposes. Third, "culture camp" is increasingly seen as a strategy to enhance the well-being of indigenous communities. In conclusion, I argue that indigenous land-based pedagogy should be understood as a part of larger plan for indigenous communities to regain their food sovereignty. This includes a movement to change the regulation on subsistence activities and traditional food in favor of indigenous communities.
\end{abstract}

\section{1. 食料主権と食料安全保障}

本稿では, 内陸アラスカ先住民社会において盛んに行 われている生業と伝統食の復興・継承を目指す取り組み を報告し, 食料主権の観点から考察する。著者は2012年 から2016年にかけて, 内陸アラスカのクスコクィム川上 流域に位置するニコライ村で, 計14か月間の民族誌的調 査を行った。本稿では, 現地調査で得られた資料を主に 扱うが，補足的に他の取り組みについても言及する。

真嶋良孝によれば，食料主権（food sovereignty）と は「すべての国と民衆が自分たち自身の食料・農業政策 を決定する権利である。それは, すべての人が安全で栄 養ある豊かな食料を得る権利であり, こういう食料を小 農・家族経営農民, 漁民が持続可能なやり方で生産する

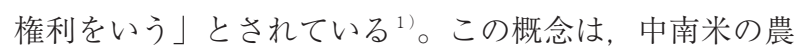
民運動に由来する世界的な社会運動組織ビア・カンペ シーナが, 世界貿易機関（WTO）の推進する新自由主 義的体制に対するオルタナティヴとして1996年に提唱し
た。

当時, 国際的な連携に基づく飢餓対策が進められる中 で，食料安全保障（food security）という別の概念が論 じられていた。国連食糧農業機関（FAO）の定義によれ ば，「活動的かつ健康的な生活を送るために必要となる 食事のニーズと食物の好みを満たすような, 十分な量で 安全かつ栄養価が高い食べ物に対する物理的, 社会的か つ経済的なアクセスをあらゆる人々がいつでも有してい るとき」(著者訳) に, 食料安全保障は実現されている と言える。ビア・カンペシーナは, 食料安全保障の論者 が食料の生産とそれへのアクセスを論じるにとどまり, それがどのように誰によって生産されているかに関して さほど注意を払っていないことを批判している2)。つま り,ここで問題とされているのは, 食料安全保障がグロー バルなレベルでの食料生産と配分に焦点化する傾向があ るのに対して, 食料主権はローカルなレベルでの食料生 産に関する意思決定を尊重するという視点の違いである。 


\section{2. 食料と政治のつながり}

だが，ローカルと言っても，食料主権が論じられる文 脈によってさまざまな振れ幅がある。日本で食料主権が 論じられるひとつの大きな文脈は, 冒頭に引用した真嶋 が寄稿する論集 ${ }^{3}$ のように自由貿易協定への異議申し立 てであった。この場合，ある国の農民が外国や多国籍企 業に対して食料政策の自己決定をする権利を行使するこ とを求めて，国などの関係者に働きかけている。この文 脈における「主権」は，「ある国が外国や多国籍企業に 対してもつ内政不干渉の権利」(対外主権) と「国民が 国政のあり方を最終的に決定する権限」（国民主権）が 想定されている。先住民研究の文脈から言えば，少なく とももうひとつの「主権」が考えられる必要がある。そ れは，「国家に対して先住民がもつ民族自決権」（先住民 の主権）である。

なぜこのような言挙げをするのかと言うと, 北米先住 民社会と国家の関係において，先住民の食文化に対する 不当な抑圧が悲惨な結果を招いたという歴史的な事実が あるからだ。く知られているのは，19世紀後半のアメ リカ大平原におけるバイソンの大量殺翏である。この時 代，アメリカ陸軍は，大平原の先住民社会と交戦中であ り, バイソンを重要な食料源とする先住民社会を兵糧攻 めにすることを目的として，バイソンの狩猟を奨励した と言われている ${ }^{4)}$ 。10数年のうちにバイソンの生息頭数 は大幅に減少し, 絶滅が危惧されるほどとなった。食料 源を失った大平原の先住民社会は, 居留地に移動し, 農 耕を受け入れるしかなかったと言われている。

本稿で取り上げる内陸アラスカ先住民社会においても， 「食料」と「政治」は深い結びつきを示している。著者 が通うクスコクィム川上流域では，気候条件的に農耕は まったく不可能というわけではないが制限が大きいため, ヘラジカやカリブーの狩猟, サケ類の漁掞が, 重要な食 料資源となっている。1960年代, アラスカ州政府はサケ の資源保護を理由として, サケ漁用のヤナを一方的に禁 止した ${ }^{5)}$ 。同じく現地の自然資源管理当局は, 肉が必要 な者は自由にへラジカを獲ってもよいという先住民社会 の伝統的な考え方に配慮せず，ヘラジカの猟期を定めて， 期間外の狩猟を「密猟」とみなして取締りの対象として
いる。もちろん, このような規制を設ける側は自然資源 の「適正な」管理を謳っているが，先住民社会の側は非 先住民が行うスポーツ狩猟やスポーツフィッシングに対 する規制の甘さなどさまざまな点で疑問を感じており， 狩猟や漁撈に対する規制を先住民社会に対する同化政策 の一部と捉えている。

\section{3. 文化キャンプ}

内陸アラスカ先住民社会では,「文化キャンプ」と呼 ばれる, 生業と食文化の再活性化を目指す取り組みが盛 んである。このような活動は, アラスカ先住民の若者が 古老たちと数日〜 1 か月間ほどキャンプ生活をともにす るなかで, 先住民の「文化」について体験的に学ぶこと を目的としている。

\section{(1) 文化キャンプの実際}

ニコライ村では，表 1 のよなスケジュールで「文化 キャンプ」および関連する生業の再活性化を目指す取り 組みが実施されている。学期期間中は学校がおもな実施 主体となり, 夏季休業期間中は村評議会（村に住む先住 民の利益を代表する機関）が担当している。日程は 1 週 間弱の場合が多い。例えば, 毎年 7 月にマスノスケの遡 上時期に合わせて行われる「サーモンリバー文化キャン プ」では, 児童生徒およびその保護者らが合計 20 ～ 30 人 集まり, マスノスケ漁, 燻製作り, ヘラジカ猟と解体調 理を実践する。ニコライ村は狩猟と漁掞が盛んであり, 参加するほとんどの保護者（児童生徒の親もしくは祖父 母にあたる）は，これらの活動を普段から行っているか， 少なくとも若い頃には頻繁に経験していた。児童生徒は, 保護者らもしくは親戚, 隣人・友人などのやり方を真似 しながら試行錯誤をして技能を身につけていく。

\section{（２）食料主権の観点から見た文化キャンプ}

食料主権の観点から考えると,「文化キャンプ」は, ヨー ロッパ系アメリカ人による植民地化の影響を受けて抑圧 されたアラスカ先住民の生業と食文化を再活性化させ, 次世代に継承させようとする試みであると言える。アラ スカ先住民がマジョリティとなる集落の多くは，アラス カハイウェイと接続しておらず, 都市部からの移動には

表 1 ニコライ村における生業の再活性化に関する取り組み

\begin{tabular}{|c|c|c|c|c|c|c|}
\hline 名 称 & 主 催 & 時 期 & 日 程 & 場 所 & 内 容 & 参加者 \\
\hline 春のキャンプ & 学校 & 5 月 & 4 泊 5 日 & 野営地 & 水鳥猟, 網漁, 採集, ビーズ細工 & 30人 \\
\hline $\begin{array}{c}\text { 捕魚車作り } \\
\text { (2014年のみ) }\end{array}$ & 評議会 & 6 月 & 10日間 & 村の川岸 & 捕魚車の作成, 設置, 漁撈 & $3 \sim 20$ 人 \\
\hline 文化キャンプ & 評議会 & 7 月 & 6 泊 7 日 & 野営地 & サケ漁, ヘラジカ猟, 解体·調理 & 20〜30人 \\
\hline 秋のキャンプ & 学校 & 9 月 & 2 泊 3 日 & 野営地 & ヘラジカ猟, 水鳥猟, 解体 · 調理 & $20 \sim 30$ 人 \\
\hline 水下漁 & 学校 & 3 月 & 日帰り & 村付近の湖 & 水下漁 & 10人 \\
\hline
\end{tabular}


航空機が利用されるのが一般的である。アラスカ先住民 の村落では，狩猟・漁撈・採集および近隣との交易に よって食料自給度がきわめて高い生活様式が維持されて きたが, 後述するさまざまな要因によって, 徐々に外部 から輸入される食料品が利用される機会が増えていった。 「文化キャンプ」のような活動は，アラスカ先住民社会 においてきわめて重要な食料生産活動としての狩編・漁 掞を, 若者が主体的に学ぶ機会を設けることで, 外部か ら輸入される加工食品への依存を減らし，より自律的な ローカルフードシステムを構築することを目指している。 いわばフードシステムの脱植民地化のための取り組みで ある。

ニコライ村では,「いつか白人の食べ物が来なくなる ときが来る」という言い伝えがあり，村人の見解によれ ば，「文化キャンプ」は輸入食品に頼ることができず, 自給自足の生活を送る必要が生じるかもしれない未来に 備えるための対策としての意味合いを有している。内陸 アラスカのコミュニティレベルにおける「食料安全保障」 は, 先住民の食料主権の（再）確立を積極的に進めるこ とを通して追求されている。

\section{（3）食料主権の（再）確立に貢献する文化キャンプの 3 側面}

「文化キャンプ」は，相互に関連する 3 つの側面から 食料主権の (再) 確立に貢献する。

第一に, 学校教育と社会教育の関わりがある。内陸ア ラスカを含む北アメリカ先住民の生業と食文化にまつわ る知識や実践は, 先住民コミュニティの日常生活のなか で学習されてきたものである。しかし，アラスカ先住民 の子弟を対象として行われた従来の学校教育は, コミュ ニティ内の日常生活との関わりが薄い点で彼らの学習意 欲を削ぐのみならず，先住民言語への厳しい抑圧を含む 同化を目的とした教育であった点が批判を集めてきた ${ }^{6)}$ 。 学校教育は, 先住民コミュニティがみずからの子どもた ちをみずからの文化に基づいて育てる権利を（意図的に も非意図的にも）侵害してきたと言える。

アラスカでは, 1970年代以降, 先住民社会と学校教育 の関係をどのように改善できるかという問題が, 教育学 者の間で盛んに議論されるようになった ${ }^{7-9)}$ 。そのよう な議論のなかで，先住民の世界観と西洋のそれを対等な 「知識体系」として扱った上で両者をともに学ぶ方法が 模索されるようになってきた。「文化キャンプ」は, 村 の子どもたちと学校教育関係者が, 古老たちの指導を受 けながら先住民の生活を体験してみることで, 地域コ ミュニティの伝統文化についてその文化の学習者にふさ わしいやり方で学ぶ方法として取り上げられた ${ }^{10)}$ 。非先 住民による学校教育が先住民の社会教育（コミュニティ 内での子弟教育) を軽視・抑圧してきた従来の関係に対 して,「文化キャンプ」は, 学校教育の側が社会教育の 内側にみずからを位置づけ, 積極的に地域社会（先住民
コミュニティ）から学ぶ場を作る試みである。

このように「文化キャンプ」は，地域社会の主体的な 関わりがあってはじめて実現可能なものであり，もとも と社会教育的な観点から自主的に行われてきた先住民コ ミュニティ内の活動と, 前述したような教育学者の関心 が合流するような形で成立したと考えられる。とりわけ， ニコライ村の「サーモンリバー文化キャンプ」は, 先住 民関連の組織の支援を受けて, 村評議会が主体となって 実施しており, 夏季休業期間中の活動であるため学校教 育関係者は関与していない。そのため, この活動はとく に社会教育の要素が強い取り組みであると位置づけられ る。内陸アラスカ先住民社会のなかで, このような取り 組みに対する要望が強いのは, 前述したようにコミュニ ティ内の「食料安全保障」に対する懸念が強いからであ る。

第二に，学校教育と協働することで自然資源管理の法 律に縛られずに生業活動を実践できるというメリットも 存在する。「文化キャンプ」における学習法は, 実際に 生業活動の現場に立ち会い, 観察し, 実践することで身 につける「正当的周辺参加」の好例と呼べるものである。 そのため,「文化キャンプ」で行われる生業活動は, 日 常的に行われるものとほとんど差がない。文化キャンプ の開催時期である 7 月, サーモンリバーではマスノスケ 漁のかたわらへラジカ編が伝統的に行われていたが, 現 在では, この時期の狩編は州の野生生物警察官からは「密 猟」とみなされる。「サーモンリバー文化キャンプ」を 実施する際にも, 期間外のヘラジカ狩編に関する許可申 請がおこなわれ，そのような許可のもとに狩りがなされ た。先住民文化の「教育活動」として「文化キャンプ」 を企画することで, 自然資源管理の適用外とすることが できる。そのため, 「文化キャンプ」には，村の実情に 合わない自然資源管理の法律と取り締まりに対する一時 的な対応策としての側面もある。

第三に，「伝統文化」に沿った生活をすることで，健 康的なライフスタイルを送ることができるという考え方 がある。「文化キャンプ」のような合宿型のプログラムは, アルコール依存症患者の治療, もしくはアルコールや薬 物に依存しない健全なライフスタイルの啓発を目的とし て実施される場合がある。「文化キャンプ」がときに「ウェ ルネスキャンプ」と呼ばれることがあるのはその所以で ある。例えば, 最近では内陸アラスカ先住民の 42 村落が 合同で作るコンソーシアムであるタナナ首長会議が「文 化・ウェルネスキャンプ」開催のための助成金を獲得し ているが, それぞれの村では伝統文化の学習に合わせて 健康増進のためのプログラムを実施することが求められ ている。

このような動きの背景には, 伝統文化への誇りを持ち, さまざまな活動に積極的に参加する者は, アルコールや 薬物に依存することのない健全な生活を送ることができ るという考え方がある。また，健全な身体があってこそ， 
狩猟文化を守ることができるとも言えるだろう。

\section{4. 結 論}

本稿では, 内陸アラスカ先住民社会における生業と伝 統食文化の復興に向けた取り組みを, 食料主権の観点か ら紹介してきた。著者は, 食料主権と先住民社会の接点 に関して, 以下のような相互に関連する 4 つの論点を考 えている。

A. その社会にとって栄養学的, 社会的, 精神的に重 要な動植物種の保全

B. 技術・慣習・世界観の継承と共有

C. 生業や食文化を実践する場の確保（自然環境面・ 社会の両方）

D. 資源管理の関連法規との兼ね合い

アメリカ大平原の先住民社会が，バイソンが絶滅寸前 に追い込まれることで大きな打撃を受けたことからわか るように，Aの視点は， B〜Dの基盤となる項目である。 生業の対象となる種が絶滅してしまえば，それに付随す る生業の技術や慣習，世界観も継承されなくなってしま う恐れが高くなる（B）。そして，そのような先住民の 実践や世界観は，座学で教えられるものというよりは実 際の体験のなかで学習されるものが圧倒的に多いため, それらを可能とする自然環境面, 社会面の整備が必要と なる（C）。本稿で簡単に紹介したような自然のなかで の活動は資源管理の法律によって管理されているので, 伝統的生業と食文化を継続していくためには法律面での 調整も欠かせない（D)。

それでは，栄養学は先住民社会における生業と伝統食 文化の復興にどのように関わることができるのだろうか。 ひとつの可能性は, 人々がその土地で生活を送る上で伝 統食が担ってきた役割を科学的に実証することによって， 権利（再）獲得への貢献をすることが考えられる。例え ば, アラスカ北極海沿岸のコッツビューという町では, アラスカ先住民が住む他の地域と同じく，老人ホームで の食事が問題となっていた。この施設は, 連邦政府から の資金援助を受けているため, 衛生と栄養管理の都合上, アメリカ合衆国農務省の許可を受けた食品しか提供でき なかった。だが，アザラシ，クジラ，カリブーなどの野 生動物を中心とした食文化を有するイヌピアットの古老 から見れば，このような外来食品は食べ慣れないもので あり，不満が大きかった。いわば，農務省が定義する「食 の安全」と「食料安全保障」がイヌピアットの食文化と 相いれないため, イヌピアットの人々の「食料主権」が 十分に保障されない状況が生じていたと言える。

2010年代前半にかけて，老人ホームの管理者，先住民 出身の医師，政治家が協力関係を築き，この問題を是正 するための運動を行った。その結果，2014年の農業法改 正に合わせて，伝統食の一部が公共施設において提供で きるようになった。ある記事によれば，2016年の時点で は, 新しく認められた食品のなかに現地で常食されるア
ザラシ油が含まれていないため, 老人ホームの管理者と 栄養学者が協働して，アザラシ油の認可を得るための取 り組みを行っているという ${ }^{11)}$

上記の事例は，本稿で扱ってきた「文化キャンプ」の ような先住民野外教育プログラムと一見関係が薄いよう に見える。だが，食料主権の（再）獲得という広い観点 から見れば，「文化キャンプ」はおもにBに焦点を合わ せた活動，伝統食をめぐる法律改正の運動はCとDを目 指したものであり，両者は食料主権を実現する上での異 なった側面へのアプローチとして整理することができる。 「食料主権」という目標に向かって, さまざまなアプロー チを有機的に絡み合わせることが有効な戦略であると考 えられる。実際, 前述したタナナ首長会議は,「文化・ウ工 ルネスキャンプ」に資金援助を始めるのみならず，食料 源であるマスノスケの個体数が減少している問題への対 策として「狩猟・漁撈・採集タスクフォース」を組織し, アラスカ先住民による自然資源管理を実現するための運 動を行っている。

著者は，2017年 6 月にカナダ・バンクーバーで開催さ れたアメリカ先住民研究学会に参加した。そのときに「食 料主権」をタイトルに掲げる分科会が散見されたことは, 非常に驚きであった。カナダでは，先住民コミュニティ， 栄養学者, 生物学者, 教育学者らが参加する大規模な研 究・実践プロジェクトが組織され, 食料主権に関して分 野横断的な研究・実践が行われている例もある ${ }^{12)}$ 。今後, 先住民研究において, 食料主権はますます重要なキー ワードとなっていくことが予想される。

\section{文献}

1）真嶋良孝：食料主権のグランドデザイン（村田武編）, 食 料危機・食料主権と「ビア・カンペシーナ」, 農村漁村文化 協会, 東京, pp. 125-160 (2011)

2 ) Wittman H, Desmarais A A, Wiebe N eds.: Food Sovereignty: Reconnecting Food, Nature and Community, Fernwood Publishing (2010)

3) 村田武編：食料主権のグランドデザイン, 農村漁村文化 協会, 東京 (2011)

4 ) Smits D D: The Frontier Army and the Destruction of the Buffalo: 1865-1883, The Western Historical Quarterly, 25, 312338 (1994)

5) Holen D L, Simeone W E, Williams L: Wild Resource Harvests and Uses by Residents of Lake Minchumina and Nikolai Alaska, 2001-2002 (ADFG Technical Paper 296), Alaska Department of Fish and Game (2006)

6) Dauenhauer R L: Conflicting Visions in Alaskan Education, University of Alaska Fairbanks (1997)

7 ) Barnhardt R: Culture, Community, and the Curriculum, Center for Cross Cultural Studies, University of Alaska Fairbanks (1981)

8) Kawagley A O: Yupiaq Worldview: A Pathway to Ecology and Spirit, Waveland Press (1995)

9) Barnhardt R, Kawagley A O eds.: Alaska Native Education: Views from Within, Alaska Native Knowledge Network (2010) 


\section{食料主権論からみたアラスカ先住民の生業と伝統食の現在}

10) Murphy B C.: Culture Camp: Examining the Teaching and Learning at the Convergence of Traditional Knowledge and Western Science (M.A. Thesis), University of California, Davis (2010)

11) Reisman J: The Fight for the Right to Eat Seal Blubber, http://www.slate.com/articles/health_and_science/medical_ examiner/2017/10/the_fight_for_the_right_to_eat_seal_ blubber.html

(Published on October 9, 2017; Last accessed on April 4, 2018)

12) Robidoux, M A, Courtney W M eds.: A Land Not Forgotten: Indigenous Food Security and Land-Based Practices in Northern Ontario, University of Manitoba Press (2017)

本稿は,「北海道の食」をテーマとした第 55 回大会講演をまとめたものである。 